\title{
Measuring relational norms: some methodological issues
}

\author{
Keith J. Blois \\ Templeton College, University of Oxford, \\ Oxford, OX15NY \\ Great Britain. \\ keith.blois@sbs.ox.ac.uk \\ Tel: 01865-422700

\section{Bjoern S. Ivens} \\ Department of Marketing, \\ Friedrich-Alexander University Erlangen-Nuremberg, \\ D-90403 Nuremberg \\ Germany \\ bjoern.ivens@wiso.erlangen.de, \\ Tel: 0049-911-5302-218
}

\begin{abstract}
This study questions the validity of the operationalisations of Macneil's norms which have been used in published studies. It compares the evaluation of two B2B exchanges using features that are fundamental to arguments which underpin Macneil's concepts. The discrepancies between the results are statistically significant.
\end{abstract}

Keywords: Norms, relational contracting theory, measurement, scales 


\section{Introduction}

Macneil's study of the role of norms in exchanges first came to major prominence with the publication in 1980 of his book "The New Social Contract: An Inquiry into Modern Contractual Relations". Prior to this his work had only been published in law journals (e.g. Macneil, 1974) but shortly after 1980 his ideas began to be discussed within the discipline of management studies and, not least within this broad field, it attracted the interest of marketing scholars. While it cannot be claimed that Macneil's work was the sole impetus for or source of a growth in marketing scholars' interest in the role of norms in the management of B2B exchange processes there can no doubt Macneil's work has been a major influence. Indeed, a search of the ABI Inform Global Quest database identified 33 studies published between 1984 and 2001 which used norms as a central concept and, at least, referred to one or more of Macneil's studies'. Of these 33 studies 24 incorporated empirical work. As Table I shows, in the context of their explanations of how these 24 papers developed the measures of relational norms that they used, Kaufmann and Stern (1988) was the paper most frequently referenced. Indeed a number of these 33 papers did not just refer to Kaufmann and Stern's paper but directly utilised some or all of their scales. Thus there is a strong link to Macneil's thinking because Kaufmann and Stern not only stated "We build on Macneil's theory of Relational Exchange" (Kaufmann and Stern, 1988, p.535) but they also had the benefit of personal conversations with Macneil when preparing their paper.

An interesting feature of these empirical studies is that no study has developed measures of all of Macneil's ten common contract norms. Some studies only use measures of a subset of these common contract norms. Others use a subset together with scales that they have either derived from other writers' publications and/or those they have developed themselves. Thus Kaufmann \& Stern (1988) developed scales to measure only three of Macneil's common contract norms: 'Role integrity'; 'Contractual solidarity'; and, 'Reciprocity'. In comparison Noordewier, et al. (1990) developed a composite relational governance measure based upon measures of: supplier flexibility; supplier assistances; information provided to the supplier; monitoring of the supplier; and expectations of continuity. Of these five elements only their concept of 'Supplier flexibility' seems to be associated with Macneil's norms.

Furthermore, even where two or more writers have investigated the same norms, except where they explicitly use other writers' scales, there seems to be little agreement as to how the scales should be operationalised. Indeed in cases where it might be expected that the same or at least very similar scales would be utilised quite different scales are used without explanation. This is illustrated by the studies of Kaufmann \& Stern (1988) and Kaufmann \& Dant (1992) which both developed operationalisations of the norm of 'Reciprocity'2 yet, not only did Kaufmann \& Stern use three statements where Kaufmann \& Dant used five, but there were considerable differences between these statements (see Table II). This is perplexing as obviously Kaufmann \& Dant were aware of Kaufmann \& Stern's earlier study but, even so, they do not explain why they developed alternative measures.

1 Macneil has been a prolific writer and, on his own admission, he has constantly changed and developed his ideas. This means that it is particularly important to note the date of any reference to Macneil's work.

2 In work published after 1983 Macneil replaced the label 'Mutuality' with 'Reciprocity' but Kaufmann and Stern (1988) disregarded, without explanation, this change in Macneil's view. 
Table 1 Cross-referencing and utilization of measures of scales
between a selection of studies

\begin{tabular}{|c|c|c|c|c|c|c|c|c|}
\hline & $\begin{array}{l}\text { Kaufmann } \\
\& \text { Stern } \\
1988\end{array}$ & $\begin{array}{l}\text { Noordewier, } \\
\text { et al. } 1990\end{array}$ & $\begin{array}{l}\text { Heide } \\
\& \\
\text { John } \\
1990 \\
\end{array}$ & $\begin{array}{l}\text { Boyle } \\
\text { et al. } \\
1992\end{array}$ & $\begin{array}{l}\text { Kaufmann } \\
\text { \& Dant } \\
1992\end{array}$ & $\begin{array}{l}\text { Heide } \\
\& \\
\text { John } \\
1992 \\
\end{array}$ & $\begin{array}{l}\text { Gundlach } \\
\& \text { Achrol } \\
1993\end{array}$ & $\begin{array}{l}\text { Heide } \\
1994\end{array}$ \\
\hline $\begin{array}{l}\text { 1. Kaufmann \& } \\
\text { Stern } 1988\end{array}$ & - & & & & & & & \\
\hline $\begin{array}{l}\text { 2. Noordewier, } \\
\text { et al. } 1990\end{array}$ & $\boldsymbol{R}$ & - & & & & & & \\
\hline $\begin{array}{l}\text { 3. Heide \& } \\
\text { John } 1990\end{array}$ & $\boldsymbol{R}$ & & - & & & & & \\
\hline $\begin{array}{l}\text { 4. Boyle et al. } \\
1992\end{array}$ & $\boldsymbol{U}$ & $U$ & & - & $U$ & & & \\
\hline $\begin{array}{l}\text { 5. Kaufmann \& } \\
\text { Dant } 1992\end{array}$ & $\boldsymbol{R}$ & & & & - & & & \\
\hline $\begin{array}{l}\text { 6. Dant \& } \\
\text { Schul } 1992\end{array}$ & $U$ & & & & & & & \\
\hline $\begin{array}{l}\text { 7. Dwyer \& } \\
\text { Gassenheimer } \\
1992\end{array}$ & $\boldsymbol{R}$ & $\boldsymbol{R}$ & & & & & & \\
\hline $\begin{array}{l}\text { 8. Heide \& } \\
\text { John } 1992\end{array}$ & $U$ & $U$ & & & & - & & \\
\hline $\begin{array}{l}\text { 9. Heide \& } \\
\text { Miner } 1992\end{array}$ & $\boldsymbol{U}$ & & & & & & & \\
\hline \multicolumn{9}{|l|}{$\begin{array}{l}\text { 10. Dwyer } \\
1993\end{array}$} \\
\hline $\begin{array}{l}\text { 11. Gundlach } \\
\text { \& Achrol } 1993\end{array}$ & $\boldsymbol{R}$ & $\boldsymbol{U}$ & & $U$ & $U$ & $\boldsymbol{U}$ & & \\
\hline 12. Heide 1994 & $U$ & & & & & & & - \\
\hline $\begin{array}{l}\text { 13. Pilling et al. } \\
1994\end{array}$ & $\boldsymbol{R}$ & & $\boldsymbol{R}$ & & & & & \\
\hline $\begin{array}{l}\text { 14. Simpson \& } \\
\text { Paul } 1994\end{array}$ & & $\boldsymbol{U}$ & & & $\boldsymbol{U}$ & & & \\
\hline $\begin{array}{l}15 . \\
\text { Gassenheimer } \\
\text { et al. } 1995\end{array}$ & & & & & & $\boldsymbol{R}$ & & \\
\hline $\begin{array}{l}\text { 16. Gundlach } \\
\text { et al. } 1995\end{array}$ & $\boldsymbol{R}$ & $\boldsymbol{R}$ & & & $\boldsymbol{R}$ & $\boldsymbol{R}$ & $U$ & \\
\hline \multicolumn{9}{|l|}{$\begin{array}{l}\text { 17. Haugland } \\
1996\end{array}$} \\
\hline $\begin{array}{l}\text { 18. Lusch \& } \\
\text { Brown } 1996\end{array}$ & & & & & & $\bar{R}$ & & \\
\hline $\begin{array}{l}\text { 19. Bello \& } \\
\text { Gilliland } 1997\end{array}$ & & & & & & & $\boldsymbol{R}$ & $U$ \\
\hline \multicolumn{9}{|l|}{$\begin{array}{l}\text { 20. Cannon \& } \\
\text { Perreault } 1999\end{array}$} \\
\hline $\begin{array}{l}\text { 21. Johnson } \\
\text { 1999 }\end{array}$ & & $\boldsymbol{R}$ & & & & $\boldsymbol{R}$ & & \\
\hline $\begin{array}{l}\text { 22. Cannon et } \\
\text { al. } 2000\end{array}$ & $\boldsymbol{R}$ & $\boldsymbol{R}$ & & & $\boldsymbol{R}$ & & $\boldsymbol{R}$ & \\
\hline $\begin{array}{l}\text { 23. Jap \& } \\
\text { Ganesan } 2000\end{array}$ & & & & & & $\boldsymbol{R}$ & & \\
\hline 24. Kim & & $\boldsymbol{U}$ & $\boldsymbol{U}$ & & & & $\boldsymbol{R}$ & \\
\hline
\end{tabular}

Table to be read as follows:

Gundlach \& Achrol's 1993 paper Referred to Kaufmann \& Stern's paper and also Utilised scales from Noordewier, et al. 1990; Boyle et al. 1992; Kaufmann \& Dant 1992; and, Heide \& John 1992. 
TABLE II The different measures of the common contract norm 'Reciprocity' used by Kaufmann \& Stern and Kaufmann \& Dant

\begin{tabular}{l}
\hline Kaufmann \& Stern (1988) \\
\hline 1. The exchange relationship our \\
organization had with the other party \\
could better be described as an "arms \\
length negotiation" than a cooperative \\
effort. (Reverse coded)
\end{tabular}

2. The other party was just another customer (supplier). (Reverse coded)

3. While it appeared likely that other transactions would follow, there was no specific expectation that the exchange relationship should continue beyond each transaction. (Reverse coded)

Kaufmann \& Dant (1992)

1. Each transaction is expected to be reconciled completely and individually. (Reverse coded)

2. Our organization assures itself that the other party is acting as we expected by precisely monitoring the other party's performance on a transaction by transaction basis. (Reverse coded)

3. Our organization monitors performance of each transaction separately to assure compliance with expectations. (Reverse coded)

4. Expectations about the performance of the other party relate to our organization's immediate goals and even temporary fluctuations in the other's performance level are unacceptable. (Reverse coded)

5. It is expected that all discrepancies in performance or payment, no matter how small, should be investigated. (Reverse coded)

A further surprising feature of these studies is their lack of attention to an aspect of Macneil's studies that he considers to be central to his ideas. Macneil comments: "Probably the most recognized aspect of my work in contract is the use of a spectrum of contractual behavior and norms with poles, labeled relational and discrete respectively." (2000a, p.876) and he states, when discussing the relational/discrete spectrum: "Certain of them (viz. the common contract norms), however, are intensified at one end and others at the other end. In the case of relational contracts in particular, some are considerably transformed." (Macneil, 2000a, p.896). Yet in the design of the empirical element of their articles none of the papers listed in Table I take account of this essential building block of Macneil's work. In particular they do not take account of his argument that the norms related to behaviour at the ends of the spectrum relational/discrete are not mirror images (see Figure 1). Indeed it was because Macneil recognized and wished to stress that 'relational' should not be used to mean the opposite of 'discrete' that he sought unsuccessfully (Macneil, 2000a, p.895) to substitute the term 'intertwined' for 'relational'.

Typically studies which evaluate the role of norms in business to business exchanges select a number of the common contract norms; develop some statements that are considered applicable to each norm; and, ask respondents to indicate the point on a Likert-type scale which best indicates their evaluation of a specific exchange situation relative to that statement. The approach followed is that the scales are "coded so that higher numbers consistently denoted greater levels of contractual integration." (Kaufmann and Dant, 1992, p.174) However, such studies do not state in comparison with what the levels of contractual integration are "greater" but imply that, where respondents agree with an aggregation of the statements, the exchange is closer to the relational end of the spectrum. Where respondents disagree, then the exchange is seen to be closer to the discrete end of the spectrum. Thus 
such studies imply that, with regard to the applicability of norms, a discrete exchange is the mirror image of a relational exchange.

The failure to take account of this aspect of Macneil's thinking is illustrated by Kaufmann and Stern's 1988 paper that "represents the first known attempt to operationalize Macneil's relational exchange norms" (Kaufmann and Stern, 1988, pp. 544-5). ${ }^{3}$ Indeed because of this status their paper has, as discussed above, influenced many of the papers that have both discussed norms and included an empirical element. Kaufmann and Stern while recognizing that "(w)hat distinguishes between discrete and relational exchange is the way general contracting norms are manifest in the parties' relationship." (1988, p.535) then investigate only three of Macneil's relational norms. They assert that these three are "the most important general contracting norms" (Kaufmann and Stern, 1988, p.535) but provide no justification to support this assertion. The three they chose were: 'Contractual solidarity'; 'Role integrity'; and, 'Mutuality' but this means that their paper takes no account of Macneil's argument that while one of the five relational norms is an intensification of 'Role integrity', 'Contractual solidarity' is only one of the two common contract norms that are significant contributors to the relational norm 'preservation of the relation' and that the common contract norm 'Reciprocity' is only one of two minor contributors to the relation norm 'preservation of the relation'. (See Table III and Figure 2).

\begin{tabular}{|l|l|}
\hline \multicolumn{2}{|c|}{ TABLE III The norms selected for measurement by Kaufmann \& Stern } \\
\hline $\begin{array}{l}\text { Macneil's relational norms and their } \\
\text { common contract components }\end{array}$ & $\begin{array}{l}\text { The common contract norms } \\
\text { measured by Kaufmann and Stern } \\
(\mathbf{1 9 8 8 )}\end{array}$ \\
\hline $\begin{array}{l}\text { Role integrity [Role integrity] } \\
\text { Preservation of the relation [Contractual } \\
\text { solidarity; Flexibility; Reciprocity; } \\
\quad \begin{array}{l}\text { Linking norms; Creation and } \\
\text { restraint of power] }\end{array}\end{array}$ & $\begin{array}{l}\text { Role integrity } \\
\text { Contractual solidarity; Mutuality }\end{array}$ \\
$\begin{array}{l}\text { Harmonisation of relational conflict } \\
\text { [Flexibility; Harmonisation with } \\
\text { social matrix] }\end{array}$ & \\
$\begin{array}{l}\text { Supracontractual relations } \\
\text { [Harmonization with social matrix] }\end{array}$ \\
$\begin{array}{l}\text { Proprietary of means [Proprietary of } \\
\text { means] }\end{array}$ \\
\hline
\end{tabular}

Note: The norms in the brackets are those common contract norms that are components of Macneil's relational norms. The norms in italics are only minor contributors to the relational norms

To summarise, Kaufmann and Stern's study takes account of:

a/ only a subset of the common contract norms which Macneil associates with relational norms; and,

b/ none of the common contract norms associated by Macneil with the discrete norms.

Thus Kaufmann and Stern's measure is biased because the subset of the common contract norms that it measures only includes norms that contribute to the relational side of the spectrum and even then not all of them. Furthermore it completely excludes those common contract norms that contribute to the discrete side of the spectrum (see Figure 2). This is

3 In a footnote to their paper Kaufman and Stern seem to contradict this claim stating:

'Macneil cites Patrick J. Kaufman's unpublished dissertation as the only known

empirical work in this area'. See Macneil (1985: fn. 114)

4

See footnote 2. 
particularly important in view of Macneil's opinion that even discrete exchanges contain a degree of relationality. Indeed he stresses this again and again commenting: "transactions may be treated as-if-discrete, but never in fact are discrete" (Macneil, 2003) $)^{5}$

Therefore it might be expected that:

a/ where an exchange situation is towards the discrete end of the spectrum, Kaufmann and Stern's scales would exaggerate the discreteness of the situation. This because where respondents wish to indicate that they perceive an exchange to be discrete they only have the option of giving a low score to statements associated with a high degree of relationality. In comparison a set of scales which encompassed both discrete and relational norms would enable respondents to nuance their evaluation of the exchange which is extremely unlikely to be purely discrete for, as Macneil has commented: "Although the discrete norm reflects the greater intensification of two of the common contract norms - implementation of planning and effectuation of consent - the other eight (viz. common contract norms) do not - indeed cannot - disappear if the contract is to be viable." (Macneil, 1983, p.360)

b/ where an exchange situation is toward the relational end of the spectrum, Kaufmann and Stern's scales would underestimate the relationality of the situation. This because Kaufmann and Stern's scales take no account of the common contract norms that contribute to three of Macneil's five relational norms.

It was therefore hypothesised that, compared with the Macneil scales, Kaufmann and Stern's measures:

a/ overestimate the degree of discreteness in a relational exchange; and,

b/ underestimate the degree of relationality in a relational exchange.

\section{An experiment}

The following experiment was designed to test whether or not a set of scales that (1) was associated with a larger set of Macneil's common contract norms than Kaufmann and Stern's study; and, (2) specifically included scales associated with Macneil's discrete norms would produce a statistically significantly different discrimination between a relational and a discrete situation.

First, two one page cases were written describing the relationship of a firm ABP with each of two suppliers RWX and NECX. The cases were written to illustrate a situation where ABP and RWX have 'a relationship' and where ABP and NECX are only involved in discrete exchanges. The use of words such as: relationship; commitment; trust; and, their synonyms was deliberately avoided in the case descriptions.

Then three seven point Likert type scales were developed for each of the seven of Macneil's common contract norms that make a significant contribution to the norms applicable to either the discrete or to the relational end of the spectrum. It was decided to use three scales per norm on the basis that using a greater number would result in respondents being asked to respond to more than twenty-one questions and this seemed likely to negatively affect response rates. On the other hand, given the relative complexity of the concepts being measured $^{6}$, to use fewer than three scales per norm would risk the loss of information.

5 Other examples of Macneil's stress on this matter include: "All exchange, even the most discrete, occurs in relations, all exchange is thereby 'relational' (Macneil, 1987, p.276); "Even the purest 'discrete' exchange postulates a social matrix" (Macneil, 2000, p.884) and, "More important is to press home at all times the point that there is no such thing in real life as a discrete transaction." (Macneil, 2000, p.896).

6 Macneil admits that the norms seem to both involve a degree of overlap and interdependency and, a "lack of clarity of expression" (Macneil, 1987, p.272). 
The scales were developed from those reported in the studies of Kaufmann and Dant (1992) and Gundlach and Achrol (1993). The scales from these two studies were used for three reasons:

a/ they had both developed scales for more of Macneil's common contract norms than other writers;

b/ both are frequently quoted as sources by other writers ${ }^{7}$; and,

c/ Kaufmann and Dant provide a listing of all the statements they used and Gundlach and Achrol give clear statements of the content of the statements that they used.

As Table IV shows they developed a different number of scales for each of five norms.

\begin{tabular}{|c|c|c|c|c|}
\hline \multirow[t]{2}{*}{$\begin{array}{l}\text { Macneil's Common } \\
\text { Contractual Norms }\end{array}$} & \multicolumn{2}{|c|}{$\begin{array}{l}\text { Contribution to } \\
\text { Macneil's: }\end{array}$} & \multirow{2}{*}{$\begin{array}{l}\text { Number of mea- } \\
\text { sures used by } \\
\text { Kaufmann \& Dant }\end{array}$} & \multirow{2}{*}{$\begin{array}{l}\text { Number of mea- } \\
\text { sures used by } \\
\text { Gundlach \& Achrol }\end{array}$} \\
\hline & $\begin{array}{c}\text { Relational } \\
\text { Norms }\end{array}$ & $\begin{array}{l}\text { Discrete } \\
\text { Norms }\end{array}$ & & \\
\hline Role integrity & Strong & None & 7 & 4 \\
\hline Reciprocity (mutuality ${ }^{8}$ ) & Weak & None & 5 & 4 \\
\hline Implementation of planning & None & Strong & 0 & 0 \\
\hline Effectuation of consent & None & Strong & 0 & 0 \\
\hline Contractual solidarity & Strong & None & 7 & 4 \\
\hline $\begin{array}{l}\text { Linking norms: } \\
\text { restitution } \\
\text { reliance } \\
\text { expectation } \\
\end{array}$ & Weak & None & 0 & 0 \\
\hline $\begin{array}{l}\text { Creation and restraint of } \\
\text { power }\end{array}$ & Weak & None & 0 & 0 \\
\hline Flexibility & Strong & None & 5 & 4 \\
\hline $\begin{array}{l}\text { Harmonization with the } \\
\text { social matrix }\end{array}$ & Strong & None & 2 & 4 \\
\hline Proprietary of means & Strong & None & 0 & 0 \\
\hline
\end{tabular}

The process of developing the scales was: to compare the scales that these two papers had individually developed for each norm; carefully to consider Macneil's statements about the norm under consideration; and, through this process to develop composite statements. An example of the two studies' scales for Harmonization with the social matrix and the resulting three scales used in this study is set out in Appendix 1.

However as Table IV shows there are five norms for which neither Kaufmann and Dant (1992) nor Gundlach and Achrol (1993) developed scales. These are:

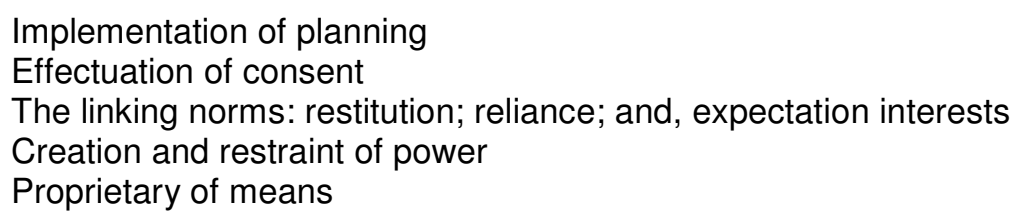

$7 \quad$ As Table I shows Kaufmann and Stern (1988) is the most frequently referenced source. However Kaufmann and Stern only developed scales for three of Macneil's ten common contract norms whereas both Kaufmann and Dant (1992) and Gunglach and Achrol (1993) each did so for five.

8 See footnote 2. 
The two norms ('The linking norms: 'restitution; reliance; and, expectation interests'; and, 'Creation and restraint of power') are only weak contributors to the norms applicable to the relational end of the spectrum and as such they were not further considered.

'Implementation of planning' and 'Effectuation of consent' are the only norms mostly strongly associated with the discrete end of the spectrum and 'Proprietary of means' is one of the common contract norms strongly associated with the relational end of the spectrum. Then three sets of scales were developed to apply to each of these three remaining norms. These scales were "theory-driven operationalisations" (Kaufmann and Dant, 1992, p.174) based on examination of the development of Macneil's thinking, as set out in his numerous papers dating from 1978 to 2000 including especially his responses to the often robust criticism of his work. The development of scales for 'Proprietary of means' is illustrated in Appendix 2.

Two sets of scales were then available for use. The first was Kaufmann and Stern's nine scales with the names of the companies in the cases incorporated into them. The second was the series of twenty-one scales (referred to hereafter as 'Macneil scales') which had been developed as described above to apply to the seven common contract norms that Macneil argues are strong contributors to either the relational norms or the discrete norms.

The two cases and the two sets of scales were translated into German (and back translated for confirmation) and tested as follows. Four classes of German students studying relationship marketing with the same lecturer; were at the same stage of the course when taking part in this experiment and of a similar constitution with regard to age and gender; were each asked to evaluate the two cases as set out in the Table V. So, Class 1 and Class 2 were asked to evaluate the ABP/RWX Case and the ABP/NECX Case respectively using Kaufmann and Stern's scales and Class 3 and Class 4 were asked to evaluate the ABP/RWX Case and the ABP/NECX Case respectively using the Macneil scales.

\begin{tabular}{|c|c|c|c|}
\hline \multicolumn{4}{|c|}{ Table V } \\
\hline & & \multicolumn{2}{|c|}{ Case evaluated using: } \\
\hline & & $\begin{array}{l}\text { Kaufmann and } \\
\text { Stern's scales }\end{array}$ & Macneil Scales \\
\hline \multirow[t]{2}{*}{ Case } & $\begin{array}{l}\text { ABP/RWX } \\
\text { (relationship) }\end{array}$ & Class 1 & Class 3 \\
\hline & $\begin{array}{l}\text { ABP/NECX } \\
\text { (discrete exchange) }\end{array}$ & Class 2 & Class 4 \\
\hline
\end{tabular}

\section{Results}

Reliability tests were applied to both sets of scales. The alpha values are documented in table VI. These values show that the scales based on Macneil produce better reliability scores on the sample used for this study than the scales documented by Kaufmann and Stern.

\begin{tabular}{|l|l|l|l|l|}
\hline \multicolumn{5}{|c|}{ Table VI Cronbach's alphas of the scales used } \\
\hline & K\&S RWX & K\&S NECX & M RWX & M NECX \\
\hline Role integrity & .65 & .64 & .94 & .91 \\
\hline Planning & & & .95 & .91 \\
\hline Conflict & & & .88 & .94 \\
\hline Solidarity & .61 & .62 & .86 & .93 \\
\hline Flexibility & & & .93 & .92 \\
\hline Harmonization & & & .91 & .94 \\
\hline Proprietary & & & .85 & .89 \\
\hline Mutuality & .60 & .63 & & \\
\hline
\end{tabular}


Following Gundlach and Achrol (1993) a composite measure of relational intensity was created by taking the average of each respondent's scores for the scales. The mean and standard deviation of these averages for each sample were calculated.

\begin{tabular}{|l|l|l|}
\hline \multicolumn{3}{|c|}{ TABLE VII The results of the experiment } \\
\hline & \multicolumn{1}{|c|}{$\begin{array}{c}\text { Kaufmann and } \\
\text { Stern's scales }\end{array}$} & \multicolumn{1}{c|}{ Macneil Scales } \\
\hline & Mean $=5.95$ & Mean $=6.14$ \\
ABP/RWX (a description of a & $\mathrm{S} . \mathrm{d}=0.429$ & $\mathrm{~S} . \mathrm{d}=.582$ \\
relationship) & $\mathrm{N}=70$ & $\mathrm{~N}=74$ \\
\hline & $\mathrm{Mean}=1.88$ & Mean $=4.23$ \\
ABP/NECX (a description of a discrete & $\mathrm{S} . \mathrm{d}=0.291$ & $\mathrm{~s} . \mathrm{d}=.372$ \\
exchange) & $\mathrm{N}=67$ & $\mathrm{~N}=69$ \\
\hline
\end{tabular}

It had been hypothesised that, compared with the Macneil scales, Kaufmann and Stern's measures:

a/ overestimate the degree of discreteness in a relational exchange and,

b/ underestimate the degree of relationality in a relational exchange.

The results set out in Table VII confirm both hypotheses. The differences between the means for the sample evaluating the relational case using Kaufmann and Stern' scales and the means for the sample evaluating the relational case using the scales developed based on Macneil are significant at the $99 \%$ confidence level. The same applies to the means for two sets of scales used to evaluate the discrete case. The results thus corroborate Macneil's view that the norms applicable to a relational exchange are not the mirror image of those applicable to a discrete exchange.

The question thus arises as to whether or not it is valid to use scales that are based on only a subset of those norms which Macneil has designated as 'common contract norms' to determine the 'relationality' of an exchange?

\section{Summary}

This paper has summarized Macneil's concept of common contract norms and indicated the extent to which these have been utilized in studies by marketing scholars. It has argued that a number of influential studies have created scales to evaluate norms have failed to take account critical aspects of Macneil's theory. A set of scales (labelled the Macneil scales) has been created which, it was argued, do take account of these aspects of his theory and an experiment has been conducted to compare these Macneil scales with those of Kaufmann and Stern. The results confirm the argument in the paper that the Kaufmann and Stern scales produce significantly biased results. 


\section{$\underline{\text { References }}$}

Bello, D.C. \& Gilliland, D.I. (1997). The Effect of Output Controls, Process Controls, and Flexibility on Export Channel Performance. Journal of Marketing, 61 (January), 22-38.

Blois, K.J. (2002). Business to Business Exchanges: A Rich Descriptive Apparatus Derived from Macneil's and Menger's Analyses. Journal of Management Studies, 39:4, 523-552.

Boyle, B., Dwyer, F.R., Robicheaux, R.A. \& Simpson, J.T. (1992). Influence Strategies in Marketing Channels: Measures and Use in Different Relationship Structures. Journal of Marketing Research, 29 (November), 462-473.

Cannon, J.P. \& Perreault, W.D. (1999). Buyer-Seller Relationships in Business Markets. Journal of Marketing Research, 36 (November), 439-460.

----, Achrol, R.S. \& Gundlach, G.T. (2000). Contracts, Norms, and Plural Form Governance. Journal of the Academy of Marketing Science, 28 (Spring), 180-194.

Dant, R.P. \& Schul, P.L. (1993). Conflict resolution processes in contractual channels of distribution. Journal of Marketing, 56:4, 38-54.

Dwyer, F.R. (1993). Soft and Hard Features of Interfirm Relationships: Am Empirical Study of Bilateral Governance in Industrial Distribution. ISBM report 6-1993, Institute for the Study of Business Markets, The Pennsylvania State University.

---- \& Gassenheimer, J.B. (1992). Relational Roles and Triangle Dramas: Effects on Power Play and Sentiments in Industrial Channels. Marketing Letters, 3:2, 187-200.

Gassenheimer, J.B., Calantone, R.J. \& Scully, J.I. (1995). Supplier Involvement and Dealer Satisfaction: Implications for Enhancing Channel Relationships. Journal of Business \& Industrial Marketing, 10 (Spring), 7-19.

Gundlach, G. T. \& Achrol, R.S. (1993). Governance in Exchange: Contract Law and its Alternatives. Journal of Public Policy and Marketing, 12:2, 141-155.

----, Achrol, R.S. \& Mentzer, J.T. (1995). The Structure of Commitment in Exchange. Journal of Marketing, 59 (January), 78-92.

Haugland, S.A. (1996). Factors Influencing the Duration of International Buyer-Seller Relationships, in Development, Management, and Governance of Relationships, Jagdish N. Sheth \& Albrecht Söllner, eds., Proceedings of the 1996 International Research Conference on Relationship Marketing, Berlin, 221-224.

Heide, J.B. \& John, G. (1990). Alliances in Industrial Purchasing: The Determinants of Joint Action in Buyer-Supplier Relationships. Journal of Marketing Research, 27 (February), 24-36.

---- \& John, G. (1992). Do Norms Matter in Marketing Relationships? Journal of Marketing. 56 (April), 32-44.

---- \& Miner, A. S. (1992): The Shadow of the Future: Effects of Anticipated Interaction and Frequency of Contact on Buyer-Seller Cooperation, Academy of Management Journal, $35: 2,265-291$.

---- (1994), "Interorganizational Governance in Marketing Channels," Journal of Marketing, 58 (January), 71-85.

Ivens, B. and Blois, K.J. (2004). Relational Exchange Norms in Marketing: A Critical Review of Macneil's Contribution. Marketing Theory, 4:3, 239-263. 
Jap, S.D. \& Ganesan, S. (2000). Control Mechanisms and the Relationship Life Cycle: Implications for Safeguarding Specific Investments and Developing Commitment. Journal of Marketing Research, 37 (May), 227-245.

Johnson, J.L. (1999). Strategic Integration in Industrial Distribution Channels: Managing the Interfirm Relationship as a Strategic Asset. Journal of the Academy of Marketing Science, 27 (Winter), 4-18.

Kaufman, P.J. \& Dant, R.P. (1992). The Dimensions of Commercial Exchange. Marketing Letters, 3:2, 171-185.

---- \& Stern, L. (1988). Relational exchange norms, perceptions of unfairness, and retained hostility in commercial litigation. Journal of Conflict Resolution, 32: 3, 534-552.

Kim, K. (2000). On Interfirm Power, Channel Climate, and Solidarity in Industrial DistributorSupplier Dyads. Journal of the Academy of Marketing Science, 28 (Summer), 388-405.

Lusch, R.F. \& Brown, J.R. (1996). Interdependency, Contracting, and Relational Behavior in Marketing Channels. Journal of Marketing, 60 (October), 19-38.

Macneil, I.R. (1974), "The Many Futures of Contracts", Southern California Law Review, 74, 691-816.

---- (1980), The New Social Contract: An Inquiry into Modern Contractual Relations. New Haven and London: Yale University Press.

--- (1981). Economic Analysis of Contractual Relations: its shortfalls and the need for a 'rich' classificatory apparatus. Northwestern University Law Review, 75:6; 1018-1063.

---- (1983). Values in Contract: internal and external. Northwestern University Law Review, 78:2, 340-418.

--- (1985). Relational Contract: What we do and do not know. Wisconsin Law Review, 483525.

---- (1987). Relational Contract Theory as Sociology: A Reply to Professors Limberg \& de Vos. Journal of Institutional and Theoretical Economics, 143, 272-290.

---- (2000a). Relational Contract Theory: Challenges and Queries. Northwestern University Law Review, 94:3, 877-907.

--- (2000b), Contracting worlds and essential contract theory. Social and Legal Studies, 9:3, 431-438.

---- (2003). "Reflections on Relational Contract Theory after a Neo-Classical Seminar" in Implicit Dimensions of Contracts, D. Campbell, Collins, H. and Wightman, J. eds. Oxford, Hart Publishing.

Noordewier, T.G., George, J. \& Nevin, J.R. (1990). Performance Outcomes of Purchasing Arrangements in Industrial Buyer-Vendor Relationships. Journal of Marketing, 54 (October), 80-93.

Pilling, B.K., Crosby, L.A. \& Jackson, D.W. (1994). Relational Bonds in Industrial Exchange: An Experimental Test of the Transaction Cost Framework. Journal of Business Research, $30,237-251$.

Simpson, J.T. \& Paul, C. (1994). The Combined Effects of Dependence and Relationalism on the Use of Influence in Marketing Distribution Systems. Marketing Letters, 5:2, 153-163. 
Figure 1 Macneil's common contractual norms and their contributions to relation and to discrete norms

\section{Discrete Norms}

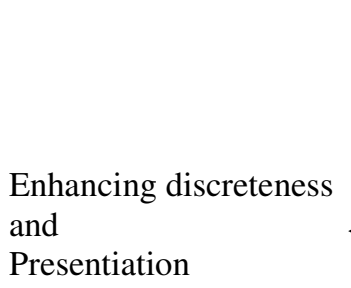

Strong links

Weak links

From: Blois 2002

\section{Common Contractual Norms}

Relational Norms

Role integrity

Role integrity

Reciprocity

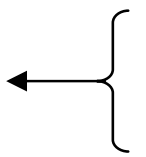

Implementation of planning

Effectuation of consent

Contractual solidarity

The linking norms: restitution; reliance; and expectation

Creation and restraint of power

Flexibility

Harmonisation with the social matrix $\longrightarrow$

Proprietary of means
Contractual solidarity

Harmonization of relational conflict

Supracontractual relations

Proprietary of means 
Figure 2 Three common contract norms selected by Kaufmann \& Stern's from Macneil's ten norms

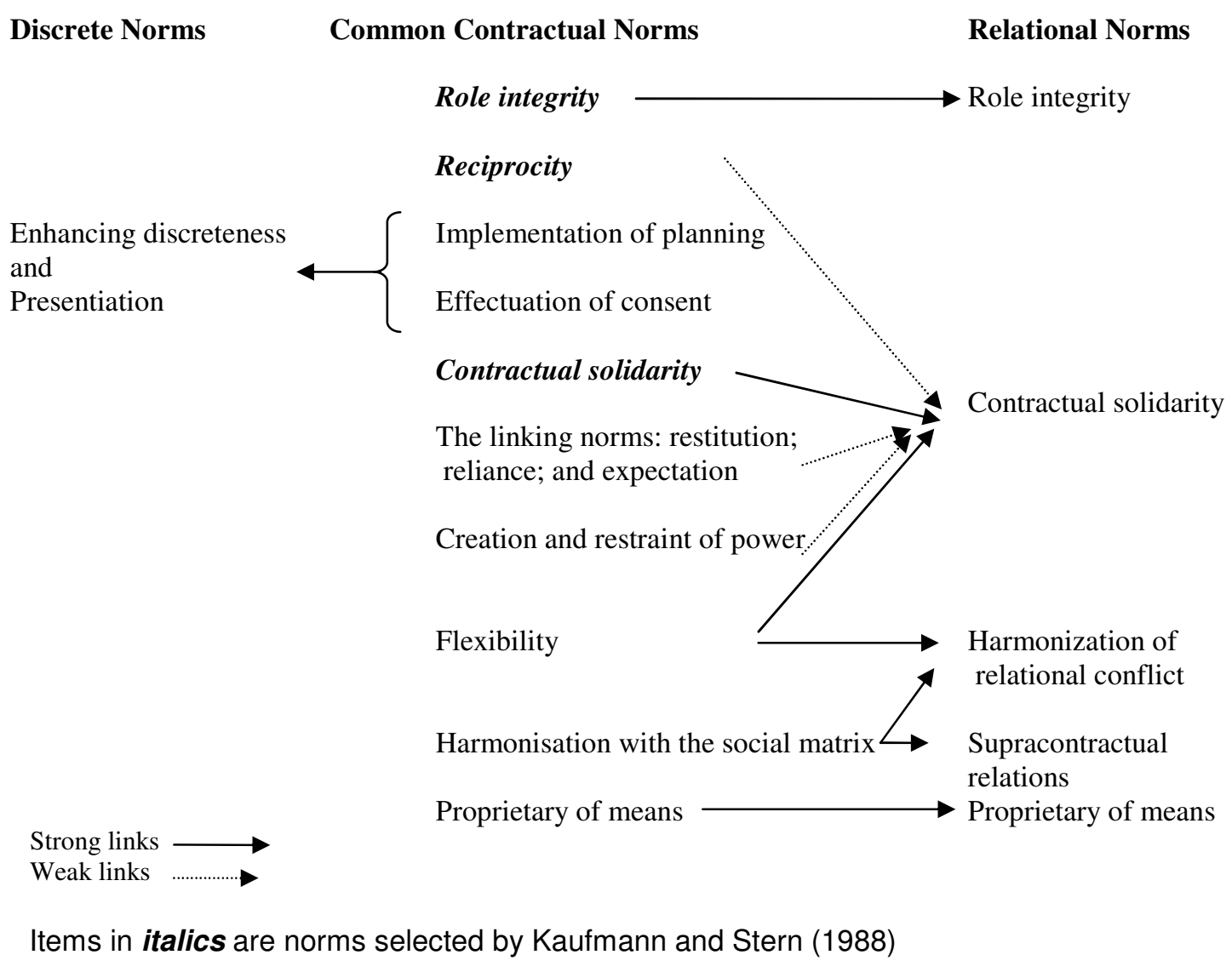




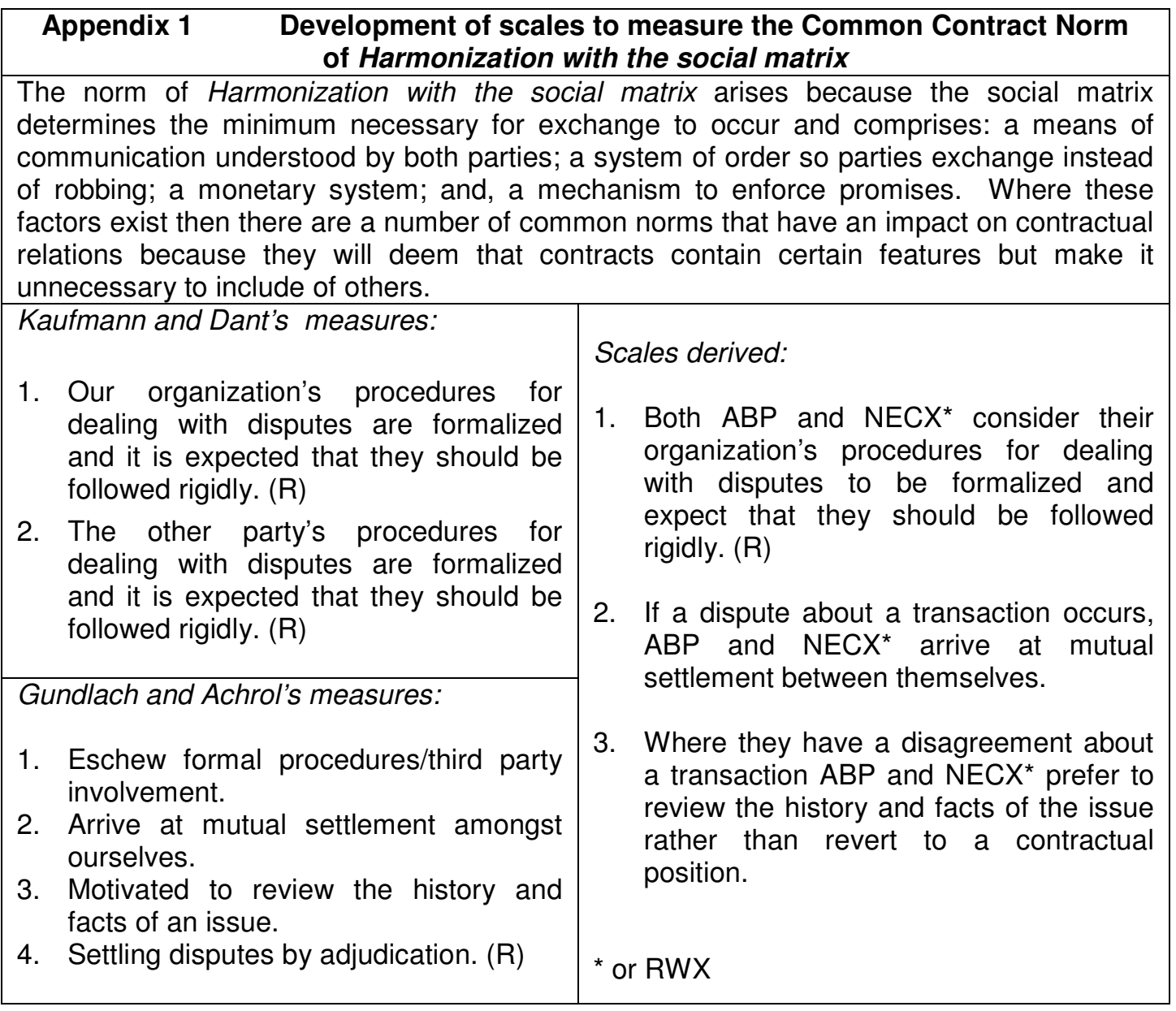

\begin{tabular}{|c|c|}
\hline $\begin{array}{r}\text { Scales developed } \\
\text { of Propri }\end{array}$ & $\begin{array}{l}\text { measure the Common Contract } \mathrm{N} \\
\text { ry of means }\end{array}$ \\
\hline Macneil's 'definition' & Scales proposed \\
\hline $\begin{array}{l}\text { "Proprietary of means: the ways relations } \\
\text { are carried on as distinct from more } \\
\text { substantive matters, including not merely } \\
\text { formal and informal procedures, but such } \\
\text { things as customary behavior, often of the } \\
\text { most subtle kind." Macneil (2000b p.432) }\end{array}$ & $\begin{array}{l}\text { 1. ABP and NECX have established ways of } \\
\text { resolving any disputes between them that } \\
\text { are unique to their relationship. } \\
\text { 2. Neither ABP nor NECX expect the other } \\
\text { to give them priority over other buyers } \\
\text { and sellers. (R) } \\
\text { 3. ABP and NECX conduct their relationship } \\
\text { strictly within the framework of the law. } \\
\text { (R) }\end{array}$ \\
\hline
\end{tabular}

